УДК 005.336.2

DOI: https://doi.org/10.35387/od.2(20).2021.177-187

Шакун Наталія Андріївна аспірантка Національного університету біоресурсів $i$ природокористування України
Shakun Nataliia - Graduate Student of the National University of Life and Environmental Sciences of Ukraine

ORCID iD: $h$ ttps://orcid.org/0000-0002-4233-168X

E-mail: tatkashakun@gmail.com

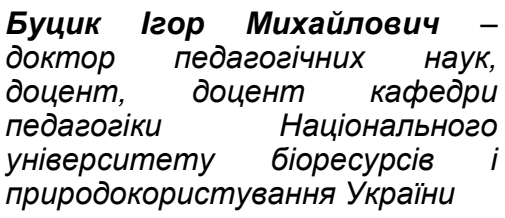

Butsyk Ihor - Doctor of Pedagogical Sciences, Associate Professor, Associate Professor of the Pedagogy Department of the National University of Life and Environmental Sciences of Ukraine

ORCID iD: https://orcid.org/0000-0002-3105-2802

E-mail: i_butsyk@ukr.net

\title{
ЗМІСТ I СУТНІСТЬ ПРОФОРІЄНТАЦІЙНОЇ КОМПЕТЕНТНОСТІ ВИКЛАДАЧА ЗАКЛАДУ ВИЩОЇ ОСВІТИ
}

Анотація. В оглядовій статті розглядається проблема визначення змісту та сутності профорієнтаційної компетентності викладача закладу вищої освіти в контексті підготовки його до здійснення профоорієнтаційної роботи, передбаченими професійними завданнями щодо залучення абітурієнтів до вступу. Виділено потребу та основні завдання профрорієнтаційної діяльності викладача закладу вищої освіти з орієнтирами на професійний стандарт.

У результаті проведеного авторами аналізу наукових праць виокремлено загальні характерні складові профрорієнтаційної компетентності, що дозволило їі розглядати як інтегровану якість особистості, об'єднану готовністю й здатністю до здійснення цілеспрямованої профорієнтаційної діяльності з майбутніми вступниками на основі попередньо сфрормованих знань, умінь, навичок, якостей, інтересів $i$ цінностей.

Авторами публікації пропонуються узагальнені результати аналізу наукових поглядів у даному напрямі, на основі чого виокремлено у змісті профорієнтаційної компетентності викладача закладу вищої освіти інтегровані компоненти (когнітивний, мотиваційно-ціннісний, діяльнісний та особистісно-рефрлексивний), які характеризуються сфрормованістю знань, умінь, навичок та якостей особистості, які покладено в основу ефрективної профорієнтаційної роботи. У результаті проведеного дослідження авторами уточнено сутність поняття «профорієнтаційна компетентність викладача закладу вищої освіти».

Ключові слова: компетентність; профоорієнтаційна діяльність; профорієнтаційна компетентність; викладач закладу вищої освіти; здатність особистості. 
Shakun Nataliia, Butsyk Ihor

\title{
CONTENT AND ESSENCE OF VOCATIONAL GUIDANCE COMPETENCE OF TEACHERS OF A HIGHER EDUCATIONAL INSTITUTION
}

\begin{abstract}
In the review article it is considered the problem of determining the content and essence of vocational guidance competence of a higher education teacher in the context of preparing him for vocational guidance work, which is provided by professional tasks in order to attract applicants to study. The need and main tasks of vocational guidance activity of a teacher of a higher education institution with orientations to the professional standard are highlighted.

As a result of the analysis of scientific works carried out by the authors, the general characteristic components of vocational guidance competence were highlighted, which made it possible to consider it as an integrated quality of personality, united by its readiness and ability to carry out targeted vocational guidance activities with future applicants on the basis of previously formed knowledge, abilities, skills, qualities, interests and values.

The authors of the publication propose the generalized results of the analysis of scientific views in this direction, on the basis of which integrated components (cognitive, motivational-value, activity and personal-reflexive) are singled out in the content of the vocational guidance competence of a teacher of higher education, which are characterized by the formation of knowledge, skills, and personality traits that are laid in the basis of an effective career guidance work. It is established that in order to carry out career guidance work a person should: have the ability to self-control, perseverance and self-exactingness, responsibility for the results of activities; he must have a purposefulness, motivation to carry out career guidance; the acquired value orientation on solving vocational guidance tasks and formed aspirations to increase the level of career guidance skills.

As a result of the research carried out by the authors, the essence of the concept of "vocational guidance competence of a teacher of a higher education institution» was clarified.
\end{abstract}

Key words: competence; vocational guidance activity; vocational guidance competence; teacher of higher education institution; person's ability.

Постановка проблеми та ї̈ актуальність. Сучасні тенденції розвитку вищої освіти в Україні створюють специфічні умови для розпалювання конкурентної боротьби між закладами вищої освіти щодо залучення нової молоді до своїх студентських лав. Уведення у підготовку фрахівців різноманітних освітньо-професійних програм, кожна з яких має свою унікальність, змушує заклади вищої освіти до організації моніторингу наявного ресурсу, пошуку та діагностики здібностей потенційних вступників, їх заохочення та інформування щодо наявних переваг та перспектив навчання саме на тій чи іншій програмі у тому чи іншому закладі освіти.

Проведені пілотні дослідження у межах вивчення сучасної практики організації профорієнтаційної роботи викладачами закладів вищої освіти дозволили виявити певні проблемні питання у вказаних процесах, 
що характеризуються неповною готовністю педагога до такого виду діяльності. Це виявляється у недостатній сформованості у викладача: знань та умінь 3 організації профорієнтаційної роботи, діагностики здібностей та нахилів учня; рівня внутрішньої мотивації до такого виду діяльності; здатності до проведення консультацій, переставлення переваг професії, доведення та переконання у реальних перспективах тощо.

Означені процеси безпосередньо впливають на ефективність заохочення молоді до вступу на ті чи інші освітні програми. Отже, така ситуація вимагає цілеспрямованої підготовки викладачів ЗВО до здійснення ефективної профорієнтаційної роботи, що, у свою чергу, залежить від рівня сфрормованості у нього профорієнтаційної компетентності. Вказане й визначає актуальність дослідження проблеми формування профрорієнтаційної компетентності викладача закладу вищої освіти.

Аналіз актуальних досліджень і публікацій. На сьогодні в науковій теорії поширені різні погляди щодо визначення поняття «профорієнтаційна компетентність». Аналіз низки наукових робіт дає можливість зрозуміти, які саме аспекти даної проблеми було досліджено: зміст, структуру та рівні готовності майбутнього вчителя до профільного навчання (Мантуленко, 2013); психологію професійного самовизначення (Клімов, 2010); профорієнтацію і професійний відбір в суспільстві (Назімов, 1972); професійну орієнтацію тих, хто навчається (Павлютенко, 1983); основні принципи організації профорієнтаційної роботи в школі та формування психологічної готовності майбутнього вчителя до профрорієнтаційної роботи (Чорна, 2013); рівні сформованості готовності до профрорієнтаційної роботи з учнями загальноосвітніх навчальних закладів в умовах профілізації навчання та методи їх визначення (Чумак, 2013); дидактичні основи курсу профорієнтації, підготовку вчителів та діагностику сформованості в них профорієнтаційної компетентності (Харламенко, 2009; Пономарьова, 2017).

Здійснений контент-аналіз наукових праць, нормативних документів і методичних розробок з проблеми організації викладачем закладу вищої освіти профорієнтаційної роботи свідчить про недостатній рівень дослідження багатьох аспектів даної проблеми, зокрема й визначення сутності профорієнтаційної компетентності, її змісту та завдань профорієнтаційної роботи. Таким чином, на даному етапі нашого дослідження завданнями наукового пошуку стало уточнення поняття «профорієнтаційна компетентність викладача закладу вищої освіти».

Виклад основного матеріалу дослідження. Згідно затвердженого професійного стандарту на групу професій «Викладачі закладів вищої освіти» (2021), до однієї із трудових функцій викладача віднесено консультативну підтримку студента, що ґрунтується на сформованій у нього здатності до здійснення індивідуального супроводу студента і передбачає надання консультацій з питань його професійного самовизначення. Оскільки вважаємо, що процес формування майбутнього фахівця розпочинається ще задовго до початку його навчання у закладі вищої освіти (формування у ЗОШ базових знань та умінь, особистісних 
якостей, професійного цілей, інтересів та мотивів, самовизначення та обрання профілів та навчальних предметів тощо), то консультування студента з питань його професійного самовизначення починається ще до моменту його вступу до закладу вищої освіти, а саме під час його профрорієнтації. А, отже, здійснювати вказану професійну діяльність має саме компетентний освітянин.

Для трактування сутності поняття «профрорієнтаційна компетентність викладача закладу вищої освіти», передусім виходили з аналізу поняття «компетентність». Здійснений аналіз освітніх нормативних документів і поглядів науковців щодо визначення сутності та складу поняття «компетентність» дав змогу встановити, що це поняття сьогодні розглядають як: коло питань, у яких людина добре обізнана; здатність особистості; здатність і готовність особистості; якість або сукупність якостей особистості; сукупність компетенцій; характеристика особистості.

Профорієнтаційну компетентність освіти ми розглядаємо як складову професійної компетентності викладача закладу вищої, оскільки одним із його сьогоднішніх актуальних професійних завдань є здійснення ефективної профорієнтаційної роботи. У сутність поняття «професійна компетентність» науковці вкладають: особистісне утворення, що містить комплекс знань, умінь, властивостей і якостей особистості, що забезпечує якісне виконання професійної діяльності (Адольф,1998; Бабюк 2009; Тюріна 2007); наявність професійних знань, умінь та навичок (Волкова, 2002; Кричевський, 1987); здатність працівника якісно виконувати свої функції, успішно опановувати нові знання та адаптуватися до змінних умов (Веснін, 1998).

На основі аналізу наукових праць і власних досліджень ми дійшли до висновку, що поняття «компетентність» слід розглядати як якість особистості, яка $€$ інтегрованою, оскільки проявляється як певне специфічне утворення, що об'єднане готовністю і здатністю особистості до здійснення цілеспрямованої діяльності у певній сфері на основі сформованих знань, умінь, якостей, інтересів та цінностей. Отже, першочергово вважаємо, що в сутності поняття «профорієнтаційна компетентність викладача закладу вищої освіти» покладено інтегровану якість особистості, що характеризується ії здатністю і готовністю до здійснення профорієнтаційної діяльності. Здатність і готовність $€$ певним інтегрованим конструктом, що складається із сформованих знань, умінь, навичок та якостей, на основі яких і здійснюється ефективна профорієнтація. Саме такий висновок дозволив нам спрямувати подальші дослідження у бік вивчення змісту профорієнтаційної компетентності та завдань профорієнтаційної роботи викладача закладу вищої освіти. 3 цією метою нами було проведено контент-аналіз наукових робіт щодо визначення складу профорієнтаційної компетентності, результати якого представлено у табл. 1. 


\section{Результати контент-аналізу наукових робіт щодо визначення профорієнтаційної компетентності}

Визначення складу профорієнтаційної компетентності

\begin{tabular}{|c|c|c|c|}
\hline \multicolumn{4}{|c|}{ Визначення складу профорієнтаційної компетентності } \\
\hline № & Тлумачення науковців & Дослідник & $\begin{array}{c}\text { Власна } \\
\text { узагальнена } \\
\text { інтерпретація }\end{array}$ \\
\hline 1. & $\begin{array}{l}\text { «Комплекс особистісних } \\
\text { можливостей педагога, які дають } \\
\text { йому змогу ефективно й доцільно } \\
\text { реалізовувати цілі та завдання } \\
\text { профрорієнтаційної роботи» }\end{array}$ & $\begin{array}{c}\text { В. Зінченко, } \\
2010\end{array}$ & $\begin{array}{c}\text { особистісні можливості } \\
\text { здійснювати } \\
\text { профрорієнтаційну } \\
\text { роботу } \\
\text { (не виокремлено } \\
\text { чіткого складу) }\end{array}$ \\
\hline 2. & $\begin{array}{l}\text { «Інтегративне особистісне } \\
\text { утворення, яке обумовлює } \\
\text { здатність ... виконувати професійні } \\
\text { функції в процесі здійснення } \\
\text { профрорієнтаційної роботи ...» }\end{array}$ & $\begin{array}{l}\text { Х. Процко, } \\
2009\end{array}$ & $\begin{array}{l}\text { здатність здійснювати } \\
\text { профорієнтаційну } \\
\text { роботу } \\
\text { (не виокремлено } \\
\text { чіткого складу) }\end{array}$ \\
\hline 3. & $\begin{array}{l}\text { «Інтегративна система, яка містить } \\
\text { здатність учителів здійснювати } \\
\text { професійні функції в процесі } \\
\text { профорієнтаційної роботи, } \\
\text { ураховуючи різні освітні потреби } \\
\text { учнів, .... спрямування } \\
\text { професійного самовизначення ....» }\end{array}$ & $\begin{array}{c}\text { В. Харламенко, } \\
2009\end{array}$ & $\begin{array}{c}\text { здатність здійснювати } \\
\text { профрорієнтаційну } \\
\text { роботу з врахуванням } \\
\text { освітніх потреб } \\
\text { (не виокремлено } \\
\text { чіткого складу) }\end{array}$ \\
\hline 4. & $\begin{array}{l}\text { «Системне особистісне утворення, } \\
\text { що інтегрує профорієнтаційні } \\
\text { знання, уміння, практичний досвід, } \\
\text { індивідуально-ділові якості й } \\
\text { забезпечує ефективність виконання } \\
\text { педагогом профорієнтаційного } \\
\text { складника професійної } \\
\text { діяльності...» }\end{array}$ & $\begin{array}{l}\text { Т. Борисова, } \\
2009\end{array}$ & $\begin{array}{c}\text { особистісне } \\
\text { утворення, що } \\
\text { об'єднує знання, } \\
\text { уміння та якості для } \\
\text { здійснення } \\
\text { проффорієнтаційної } \\
\text { роботи }\end{array}$ \\
\hline 5. & $\begin{array}{l}\text { «...Володіння домінуючими .... } \\
\text { компетенціями, які є інтегрованою } \\
\text { сукупністю знань, умінь, } \\
\text { здатностей рефлексії, комплексу } \\
\text { якостей і властивостей особистості, } \\
\text { необхідних для успішного } \\
\text { виконання професійних функцій з } \\
\text { орієнтування молоді на вибір } \\
\text { майбутньої професії....» }\end{array}$ & $\begin{array}{l}\text { П. Макарова, } \\
2005\end{array}$ & $\begin{array}{c}\text { інтегрована сукупність } \\
\text { знань, умінь і якостей } \\
\text { для здійснення } \\
\text { профорієнтаційної } \\
\text { роботи }\end{array}$ \\
\hline 6. & $\begin{array}{l}\text { «...Особиста освіта, інтегруючі } \\
\text { профорієнтаційні знання, уміння, } \\
\text { практичний досвід, особисті і } \\
\text { професійні якості, що забезпечують } \\
\text { ефективність виконання }\end{array}$ & $\begin{array}{l}\text { П. Дмитренко \& } \\
\text { І. Косяк, } 2013\end{array}$ & $\begin{array}{c}\text { системна самоосвіта з } \\
\text { урахуванням } \\
\text { попереднього досвіду } \\
\text { знань про } \\
\text { профрорієнтаційну } \\
\end{array}$ \\
\hline
\end{tabular}


профорієнтаційних функцій ...»

діяльність

У результаті проведеного аналізу було встановлено, що у більшості поглядів у профорієнтаційній компетентності науковці вбачають: особистісні можливості здійснювати профрорієнтаційну роботу (Зінченко, 2010); здатність здійснювати профорієнтаційну роботу (Процко, 2009); здатність здійснювати профорієнтаційну роботу з врахуванням освітніх потреб (Харламенко, 2009); особистісне утворення, що об'єднує знання, уміння та якості для здійснення профорієнтаційної роботи (Борисова, 2009); інтегровану сукупність знань, умінь і якостей для здійснення профрорієнтаційної роботи (Макарова, 2005); системну самоосвіту 3 врахуванням попереднього досвіду знань про профорієнтаційну діяльність (Дмитренко \& Косяк, 2013). Отже, проведений аналіз дає можливість вважати, що «профорієнтаційну компетентність» слід розглядати як інтегровану якість особистості, що характеризується здатністю і готовністю особистості до здійснення цілеспрямованої профорієнтаційної діяльності на основі попередньо сформованих знань, умінь, навичок, якостей, інтересів та цінностей.

Здійснений аналіз наукових праць щодо визначення критеріїв і показників профорієнтаційної компетентності також дозволив встановити, що профорієнтаційна компетентність, як певна інтегрована сукупність, об'єднується різними компонентами. Зокрема, у роботах Ж. Жихорської (2015) та Ж. Чумак (2013) виокремлено когнітивний компонент профрорієнтаційної компетентності, як певна система сукупність знань особистості, що складають знання: змісту та сутності профорієнтаційної роботи, їі цілей та завдань; форм, методів, прийомів і засобів виконання завдань профорієнтаційної роботи.

У наукових публікаціях Ж. Пономарьової (2017) та Ж. Чумак (2013) наголошується на тому, що до складу профорієнтаційної компетентності входить мотиваційно-ціннісний компонент, який наповнюється: сорормованістю мотивів, цілей та інтересів профорієнтаційної діяльності; спрямованістю на здійснення ефективної профорієнтаційної роботи; ціннісною орієнтацію на розв'язання профорієнтаційних завдань; емоційним задоволенням від профорієнтаційної роботи; прагненням до підвищення рівня профорієнтаційної компетентності, самовдосконалення та саморозвитку.

Організація профорієнтаційної діяльності особистості відбувається за рахунок здійснення нею певних операцій і дій, що здійснюється на основі сформованих умінь і навичок. У зв'язку із цим у роботах О. Бородієнко (2017) та Ж. Жихорської (2015) виділено операційнодіяльнісний компонент профорієнтаційної компетентності, що складається із сукупності сфрормованих умінь: щодо здійснення профорієнтаційної діяльності (проектувальних, конструктивних, комунікативних, діагностичних, організаційних); застосування методів, форм, прийомів та засобів розв'язання профорієнтаційних завдань; самоконтролю, самоаналізу й самооцінки результатів діяльності. 
Остання група умінь, що виокремлюють науковці, дозволили Ж. Денисовій (2013), Ж. Жихорській, (2015) та Ж. Чумак (2013) виділити оцінювально-рефлексивний компонент профорієнтаційної компетентності, що наповнюється сукупністю здатностей особистості 3 аналізу та оцінювання результатів власної профорієнтаційної діяльності. Також не менш важливим компонентом, на думку Ж. Денисової (2013), є емоційновольовий, який об'єднує здатність особистості до самоконтролю у діяльності, наполегливість і вимогливість до себе у роботі, відповідальність за результати тощо. Останній компонент ми розглядаємо як особистіснорефлексивний, оскільки він характеризує здатність готовності особистості до самоконтролю, самонавчання та самооцінки під час здійснення профорієнтаційної діяльності.

Отже, як свідчить проведений аналіз нормативних матеріалів і наукових праць щодо визначення змісту та сутності «профорієнтаційної компетентності», було встановлено, що вона $€$ необхідною складовою професійної підготовки викладача закладу вищої освіти, оскільки у своїй професійній діяльності педагог має виконувати ефективну профорієнтаційну роботу. У своєму змісті профорієнтаційна компетентність $€$ системним об'єднанням когнітивного, мотиваційно-ціннісного, діяльнісного та особистісно-рефлексивного компонентів, що складається із сформованих знань, умінь, навичок та якостей особистості, на основі яких здійснюється ефрективна профрорієнтаційна робота щодо залучення вступників до закладу вищої освіти.

Висновки і перспективи подальших досліджень. У результаті проведеного дослідження було уточнено поняття «профорієнтаційна компетентність викладача закладу вищої освіти» як інтегровану якість особистості, що виявляється у її здатності і готовності до усвідомлення та визначення професійних профрорієнтаційних потреб і завдань, здійснення ефективної профорієнтаційної роботи у межах викладацької діяльності, цілеспрямованого профресійно-особистісного саморозвитку. Спираючись на отримані результати досліджень, вважаємо пріоритетним напрямом подальших досліджень визначення структури профорієнтаційної компетентності викладачів закладу освіти.

\section{Список використаних джерел}

Адольф, В. А. (1998). Профессиональная компетентность современного учителя: Монография. Красноярск : КрГУ. 286.

Бабюк, М. П. (2009). Компетентністний підхід в системі вищої освіти. Вища освіта України в контексті інтеграції до Європейського освітнього простору: Теоретичний та науково-методичний часопис. Київ, 285-290.

Бородієнко, О. (2017). Критерії, показники, рівні сфрормованості професійної компетентності керівників структурних підрозділів підприємств сфрери зв'язку. URL: http://lib.iitta.gov.ua/707868

Веснин, В. Р. (1998). Практический менеджмент персонала: Пособие покадровой работе. Москва : Юрист. 96.

Волков, Н.П. (2002) Педагогіка: посібник. Київ : Академія. 576. 
Денисова, С. П. (2013). Компоненти формування професійної компетентності майбутнього вчителя початкової школи в умовах педагогічного коледжу. URL: http://visnyk.chnpu.edu.ua/?wpfb_dl=969

Дмитренко, П.В., Косяк, І.В. (2013). Формування профорієнтаційної компетентності як складової фрахової підготовки майбутніх вчителів технологій. Науковий часопис НПУ ім. М. П. Драгоманова. Серія 5. Педагогічні науки: реалії та перспективи. Зб. наук праць. Київ : НПУ. 110. 39-45.

Жихорська, О. (2015). Критерії, показники та рівні сформованості професійної компетентності навчально-допоміжного персоналу вищого навчального закладу. URL: https://seanewdim.com/uploads/3/4/5/1/34511564/zhykhorska_o._criteria_i ndicators_and_levels_of_formed_of_professional_competence_of_support staff_of_higher_education_institutions.pdf

Закатнов, Д. (2011). Профорієнтаційні засади кар'єрного розвитку учнівської молоді. Науковий вісник Інституту професійно-технічної освіти НАПН України. Серія: Професійна педагогіка. Зб. наук. праць. Київ: Вид-во ІПТО НАПН України. 86-91.

Зінченко, В. П., \& Харламенко В.Б. (2010). Формування профорієнтаційної компетентності педагога: теорія і практика: монографія. Глухів : РВВ ГНПУ імені О. Довженка. 198.

Климов, Е.А.(2010). Психология профессионального самоопределения : учебное пособие. Москва: Академия. 304.

Кричевский, В. Ю. (1987). Профессиограмма директора школы. Проблемы повышения квалификации руководителей школ. Москва : Педагогика. 212.

Макаров, П. А. (2005). Формирование профориентационной компетентности будущего учителя физической культуры: дис... кандидата пед. наук: 13.00.08. Тольятти. 278.

Мантуленко, С.В.(2013). Зміст, структура та рівні готовності майбутнього вчителя до профільного навчання. Сучасні інформаційні технології та інноваційні методики навчання у підготовці фахівців: методологія, теорія, досвід, проблеми. 35. 350-355.

Назимов, И. Н. (1972). Профориентация и профотбор в социалистическом обществе. Москва : Экономика. 254.

Павлютенков, Е. М.(1983). Профессиональная ориентация учащихся. Київ. Радянська школа. 153.

Пологовська, Ю.Ю. (2018). Критерії, показники та рівні ссрормованості профорієнтаційної компетентності у майбутніх вчителів географрії в умовах профільного навчання. Витоки педагогічної майстерності : зб. наук. праць. Полтава : ПНПУ імені В. Г. Короленка. 22. 174-180.

Пономарьова, Н. О. (2017). Готовність вчителя інформатики до профорієнтаційної роботи на IT-спеціальності як педагогічна проблема. Інформаційні технології і засоби навчання. 59, 3, 168-178.

Процко, Х. В. (2009). Підготовка майбутніх учителів технологій до профорієнтаційної роботи у загальноосвітній школі : дис... канд. пед. наук: 13.00.02. Чернігів. 233.

Стандарт на групу професій «Викладачі закладів вищої освіти». (2021). URL : 
https://mon.gov.ua/storage/app/media/pto/standarty/2021/03/25/Standart\% 20na\%20hrupu\%20profesiy_Vykladachi\%20zakladiv\%20vyshchoyi\%20osv ity_25.03.pd

Тюріна, В. О. (2007). Становлення особистості майбутніх правоохоронців на засадах толерантності їх професійної підготовки. Розвиток освіти в умовах поліетнічного регіону : матеріали міжн. наук.-прак. конференції, м. Ялта, 5-7 квітня 2007 р. Ялта : РВВ КГУ. 3. 2. 76-79.

Харламенко, В. Б. (2009). Діагностика ссрормованості профорієнтаційної компетентності майбутнього вчителя трудового навчання. Вісник Глухівського державного педагогічного університету. Серія: Педагогічні науки. Глухів : ГДПУ. 14. 210.

Чорна, І. М. (2003). Формування психологічної готовності майбутнього вчителя до профорієнтаційної роботи у школі: автореф. дис. ... канд. психол. наук: 19.00.07. Київ. 20.

Чумак, М. Є. (2013). Підготовка майбутніх учителів фрізики до профорієнтаційної роботи з учнями загальноосвітньої школи в умовах профілізації навчання: автореф. дис. ... канд. пед. наук: 13.00.04. ПереяславХмельницький. ДВНЗ «Переяслав-Хмельницький» ДПУ ім. Григорія Сковороди. 20.

\section{References (translated and transliterated)}

Adolf. V. A. (1998). Professionalnaya kompetentnost sovremennogo uchitelya: Monografiya [Professional competence of a modern teacher]. Krasnoyarsk: KrGU. 286 [in Russian].

Babiuk, M. P. (2009). Kompetentnistnyi pidkhid $v$ systemi vyshchoi osvity [Competence approach in the system of higher education]. Vyshcha osvita Ukrainy $\mathrm{v}$ konteksti intehratsii do Yevropeiskoho osvitnoho prostoru: Teoretychnyi ta naukovo-metodychnyi chasopys - Higher education in Ukraine in the context of integration into the European educational space: Theoretical and scientific-methodical journal. Kyiv, 285-290 [in Ukrainian].

Borodiienko, O. (2017). Kryterii, pokaznyky, rivni sformovanosti profesiinoi kompetentnosti kerivnykiv strukturnykh pidrozdiliv pidpryiemstv sfery zviazku [Criteria, indicators, levels of formation of professional competence of heads of structural divisions of the enterprises of sphere of communication]. URL: http://lib.iitta.gov.ua/707868 [in Ukrainian].

Vesnin. V. R. (1998). Prakticheskiy menedzhment personala : Posobiye pokadrovoy rabote [Practical personnel management: Personnel work guide]. Moskva : Yurist. 96 [in Russian].

Volkov. N. P. (2002) Pedagogika : posibnik [Pedagogy: manual]. Kyiv : Akademiya. 576 [in Ukrainian].

Denysova, S. P. (2013). Komponenty formuvannia profesiinoi kompetentnosti maibutnoho vchytelia pochatkovoi shkoly $v$ umovakh pedahohichnoho koledzhu [Components of formation of professional competence of the future primary school teacher in the conditions of pedagogical college]. URL: http://visnyk.chnpu.edu.ua/?wpfb_dl=969 [in Ukrainian].

Dmytrenko, P. V., Kosiak I. V. (2013). Formuvannia proforiientatsiinoi kompetentnosti yak skladovoi fakhovoi pidhotovky maibutnikh vchyteliv tekhnolohii [Formation of career guidance competence as a component of 
professional training of future teachers of technology]. Naukovyi chasopys NPU im. M. P. Drahomanova. Seriia 5. Pedahohichni nauky: realii ta perspektyvy - Scientific journal of National Pedagogical Dragomanov University. Zb. nauk prats. Kyiv: NPU. 110. 39-45 [in Ukrainian].

Zhykhorska, O. (2015). Kryterii, pokaznyky ta rivni sformovanosti profesiinoi kompetentnosti navchalno-dopomizhnoho personalu vyshchoho navchalnoho zakladu [Criteria, indicators and levels of formation of professional competence of teaching support staff of higher education institution].URL:https://seanewdim.com/uploads/3/4/5/1/34511564/zhykhor ska_o._criteria_indicators_and_levels_of_formed_of_professional_compet ence_of_support_staff_of_higher_education_institutions.pdf [in Ukrainian].

Zakatnov, D. (2011). Proforiientatsiini zasady kariernoho rozvytku uchnivskoi molodi [Career guidance principles of the career development of student youth]. Naukovyi visnyk Instytutu profesiino-tekhnichnoi osvity NAPN Ukrainy. Seriia: Profesiina pedahohika - Scientific Bulletin of the Institute of Vocational Education of the National Academy of Pedagogical Sciences of Ukraine. Series: Professional pedagogy. Zb. nauk. prats. Kyiv: Vyd-vo IPTO NAPN Ukrainy. 86-91 [in Ukrainian].

Zinchenko, V. P., Kharlamenko V. B. (2010). Formuvannia proforiientatsiinoi kompetentnosti pedahoha: teoriia i praktyka : monohrafiia [Formation of vocational guidance competency of a teacher: theory and practice]. Hlukhiv: RVV HNPU imeni O. Dovzhenka. 198 [in Ukrainian].

Klimov, E. A. (2010). Psikhologiya professionalnogo samoopredeleniya : uchebnoye posobiye [Psychology of professional self-determination: a textbook]. Moskva: Akademiya. 304 [in Russian].

Krichevskiy, V. Yu. (1987). Professiogramma direktora shkoly [Professiogram of the school principal]. Problemy povysheniya kvalifikatsii rukovoditeley shkol Problems of professional development of school principals. Moskva : Pedagogika. 212 [in Russian].

Makarov, P. A. (2005). Formirovaniye proforiyentatsionnoy kompetentnosti budushchego uchitelya fizicheskoy kultury : dis... kandidata ped. nauk: 13.00.08 [Formation of vocational guidance competency of the future teacher of physical training]. Toliatti. 278 [in Russian].

Mantulenko, S. V. (2013). Zmist, struktura ta rivni hotovnosti maibutnoho vchytelia do profilnoho navchannia [Content, structure and levels of readiness of the future teacher for profile training]. Suchasni informatsiini tekhnolohii ta innovatsiini metodyky navchannia u pidhotovtsi fakhivtsiv: metodolohiia, teoriia, dosvid, problemy - Modern information technologies and innovative teaching methods in training: methodology, theory, experience, problems. Vyp. 35. 350-355 [in Ukrainian].

Nazimov. I. N. (1972). Proforiyentatsiya i profotbor v sotsialisticheskom obshchestve [Career guidance and professional selection in socialist society]. Moskva : Ekonomika. 254 [in Russian].

Pavlyutenkov. E. M. (1983). Professionalnaya oriyentatsiya uchashchikhsya [Professional orientation of students]. Kyiv. Radyanska shkola. 153 [in Russian].

Polohovska, Yu. Yu. (2018). Kryterii, pokaznyky ta rivni sformovanosti proforiientatsiinoi kompetentnosti $u$ maibutnikh vchyteliv heohrafii $v$ 
umovakh profilnoho navchannia [Criteria, indicators and levels of formation of career guidance competence in future teachers of geography in the conditions of profile education]. Vytoky pedahohichnoi maisternosti Origins of pedagogical skill : zb. nauk. prats. Poltava: PNPU imeni V. H. Korolenka. 22. 174-180 [in Ukrainian].

Ponomarova, N. O. (2017). Hotovnist vchytelia informatyky do proforiientatsiinoi roboty na IT-spetsialnosti yak pedahohichna problema [Readiness of a computer science teacher for career guidance work in IT-specialty as a pedagogical problem]. Informatsiini tekhnolohii i zasoby navchannia Information technologies and teaching aids. 59, 3, 168-178 [in Ukrainian].

Protsko, Kh. V. (2009). Pidhotovka maibutnikh uchyteliv tekhnolohii do proforiientatsiinoi roboty u zahalnoosvitnii shkoli : dys... kand. ped. nauk: 13.00.02 [Preparation of future teachers of technology for career guidance work in secondary school]. Chernihiv. 233 [in Ukrainian].

Standart na hrupu profesii «Vykladachi zakladiv vyshchoi osvity» [Standard for the group of professions «Teachers of higher education»]. (2021). URL : https://mon.gov.ua/storage/app/media/pto/standarty/2021/03/25/Standart\% 20na\%20hrupu\%20profesiy_Vykladachi\%20zakladiv\%20vyshchoyi\%20osv ity_25.03.pd [in Ukrainian].

Tiurina, V. O. (2007). Stanovlennia osobystosti maibutnikh pravookhorontsiv na zasadakh tolerantnosti yikh profesiinoi pidhotovky [Formation of the personality of future law enforcement officers on the basis of tolerance of their professional training]. Rozvytok osvity $\mathrm{v}$ umovakh polietnichnoho rehionu - Development of education in a polyethnic region: materials of the international scientific-practical conference : materialy mizhn. nauk.-prak. konferentsii, m. Yalta, 5-7 kvitnia 2007. Yalta : RVV KHU. 3. 2. 76-79 [in Ukrainian].

Kharlamenko, V. B. (2009). Diahnostyka sformovanosti proforiientatsiinoi kompetentnosti maibutnoho vchytelia trudovoho navchannia [Diagnosis of the formation of vocational guidance competence of the future teacher of labor training]. Visnyk Hlukhivskoho derzhavnoho pedahohichnoho universytetu - Bulletin of Glukhiv State Pedagogical University: Pedahohichni nauky. Hlukhiv : HDPU. Vyp. 14. 210 [in Ukrainian].

Chorna, I. M. (2003). Formuvannia psykholohichnoi hotovnosti maibutnoho vchytelia do proforiientatsiinoi roboty u shkoli : avtoref. dys. ... kand. psykhol. nauk : 19.00.07 [Formation of psychological readiness of the future teacher for career guidance work at school]. Kyiv. 20 [in Ukrainian].

Chumak, M. Ye. (2013). Pidhotovka maibutnikh uchyteliv fizyky do proforiientatsiinoi roboty $\mathrm{z}$ uchniamy zahalnoosvitnoi shkoly $\mathrm{v}$ umovakh profilizatsii navchannia : avtoref. dys. ... kand. ped. nauk: 13.00.04 [Preparation of future physics teachers for career guidance work with secondary school students in terms of training profiling]. Pereiaslav-Khmelnytskyi. DVNZ «Pereiaslav-Khmelnytskyi DPU im. Hryhoriia Skovorody». 20 [in Ukrainian]. 